\title{
The Analysis of English Department Students' Difficulties in Mastering Reading Text at Muhammadiyah Aceh University
}

\author{
Siti Safura ${ }^{1, a^{*}}$ and Cut Mawar Helmanda ${ }^{1, b}$ \\ 1Department of English Education, Faculty of Islamic Studies, Muhammadiyah University, Banda Aceh, 23123, Indonesia \\ a sitisafura11@gmail.com; b bungahelmanda@yahoo.com \\ ${ }^{*}$ Corresponding Author \\ Whatsapp Number [085261826455]
}

How to Cite: Safura, S., Helmanda, C., M. (2020). The Analysis of English Department Students' Difficulties in Mastering Reading Text at Muhammadiyah Aceh University International Journal for Educational and Vocational Studies, 2(4), 560-563. DOI: https://doi.org/10.29103/ijevs.v2i4.2200

\section{ARTICLE HISTORY}

Received: 15 February 2020

Revised:28 March 2020

Accepted: 17 April 2020

\section{KEYWORDS}

Students' Difficulties;

English Department;

Mastering Reading Text;

\section{ABSTRACT}

Reading is not just as a simply reading but it requires a good understanding to get the meaning of the written text. Some students yet face difficulty in receiving the meaning of the text. So, the aim of this study is to analyze the difficulties faced by the English Department students in mastering reading text, especially about finding and understanding the main idea. It also studies how the students deal with their difficulties in Intensive Reading Comprehension class. To reach the goal, 10 students were taken randomly as the participants. Question sheets were distributed to the participants and also supported with interview. They helped the writer in collecting the data about the students' difficulties. From the gaining data, it is found that most students had problem in mastering reading text especially in understanding main idea that caused by lacking of vocabulary mastery. To deal with this problem, the students tried some ways by practicing reading aloud, having group learning, and asking the lecturer to use the appropriate technique in teaching learning reading comprehension.

This is an open access article under the CC-BY-SA license.

\section{INTRODUCTION}

Reading is an important aspect of studying English. It is one of the useful skills that should be mastered by the language learners. Someone could increase their English vocabulary, get much knowledge, and learn many things by reading. The features of any given text have a large impact on comprehension. While reading, the reader constructs various representations of the text that are important for comprehension.Readers interact with texts as they try to extract meaning and there are different types of knowledge: linguistic or systemic knowledge (bottom-upprocessing) and schematic knowledge (top-down processing). Pourhose in Gilakjani and Ahmadi (2011) stated that the main goal of reading is to gain the correct message from a textthat the writer intended for the reader to receive.

Furthermore about reading, it is the basic skill that is closely related to other skills such as writing, speaking and listening. Students are required to read lots and understand the reading material in order to achieve better result in learning process. In university level, the reading ability or competence will be taught in reading comprehension class. Reading comprehension is a complex interaction among automatic and strategic cognitive processes that enables the reader to create a mental representation to understand the information of the text (van den Broek \& Espin, 2012). It means that reading comprehension is the ability to read text, process and understand its meaning.

In every process of learning, the students could face the difficulties. It is also happened in reading class. Difficulty is the quality or state of being hard to do, deal with, or understand, the quality or state of being difficult. The language learners, either second language learners or foreign language learners, may face difficulties in comprehending English reading text. For instance, the students find some difficulties when the tutor or lecturer asked them about some information that was not mentioned clearly in the text but still in the context, let say about finding main idea. Most of the students have a great 
problems in vocabulary mastery and it made them difficult in understanding the text.

Sasmita (2012) who conducted a research to find out the students' problems in comprehending English reading texts. The findings showed that the factors that influenced the students in understanding English reading texts were related to problems in vocabulary, grammar knowledge, and reading interest. The other study which is related to the students difficulties in reading is from Atikah (2009) which was focused on finding out the students' difficulties in linguistic problem in reading comprehension and the result showed that the students find difficulties in vocabulary, grammar and spelling. The difficulties in comprehending English reading text should be known and solved by the students and the tutor or lecturer because comprehending reading text is the important skill and as an achievement indicator in reading that should be achieved by the students.

Hidayati, D (2018) has discussed it before, she did a research and concluded that some difficulties faced by the first year students of SMAN 1 Darussalam in reading comprehension test were difficulty in answering main idea questions, difficulty in answering making inference, and difficulty in answering locating reference questions. The most difficult aspect encountered by the first grade students in reading comprehension is finding main idea questions, because the location or spot of main idea. He also concluded that there are some factors that influence the students in comprehending English text. First, the students were difficult to know grammatical of sentence like using subject pronoun, object pronoun, and possessive pronoun of sentences in the text. Second, the students are difficult to understand long sentences, it made the students difficult to concentrate. Third, the effect of poor of learning media and support from the family.

In reading comprehension, Lee (2017) in Laily, R,N (2018) stated that there are 6 skills considered essentials, they are:

\section{Decoding}

Decoding is related to an early language skill called phonemic awareness which is part of a broader skill called phonological awareness. Phonemic awareness enables kids to hear individual sounds in words (phonemes). It also allows them to "play" with sounds at the word and syllable level.

\section{Fluency}

To read fluently, students need to instantly recognize word. Fluency speeds up when they can read and understand text. It is also important when students find irregular words, like of and the, which cannot be sounded out.

\section{Vocabulary}

To understand what stated in text, people need to understand most of the words in the text. Having a strong vocabulary is a key component of reading comprehension. Students can learn vocabulary through instruction but they typically learn the meaning of words through everyday experience and also by reading.

\section{Sentence Construction and Cohesion}

Understanding how sentences are built might seem like a writing skill. Connecting ideas within and between sentences, is called cohesion. But these skills are important for reading comprehension as well. Knowing how ideas link up at the sentence level helps students get meaning from passages and entire texts. It also leads to something called coherence, or the ability to connect ideas to other ideas in an overall piece of writing.

\section{Reasoning and Background Knowledge}

Most readers relate what they read to what they know. So it is important for students to have background or prior knowledge about the world when they read. They also need to be able to "read between the lines" and extract meaning even when it is not literally written.

\section{Working Memory and Attention}

These two skills are both part of a group of abilities known as executive function. They are different but closely related. When kids read, attention allows them to take in information from the text. Working memory allows them to hold on to that information and use it to gain meaning and build knowledge from what they read. Working memory and attention are part of executive function. The ability to self-monitor while reading is also tied to that. Kids need to be able to recognize when they do not understand something. Then they need to stop, go back and re-read to clear up any confusion they may have.

However, if the students find difficulties in comprehending the text, it will affect their result of study. As Oberholzer (2005) stated that "difficulty with reading can have an increasingly negative effect on the students' schoolwork and tertiary education, as reading requirements become greater and more extensive." Therefore, the writer took a topic about students' difficulties in mastering reading text, especially about understanding the main idea that covers the whole passage. By knowing the students difficulties, it will help the lecturer to find out the appropriate teaching method to help students to improve their ability in reading.

English Department in Muhammadiyah Aceh University puts big concern about reading skill. A Reading Comprehension class is provided for developing students' ability in reading. Unfortunately, the students still have problems in mastering reading text as reported through personal communication by Khairunnisawho teaches reading in the class. She said that all of the students from intensive reading class did not achieved a minimum score to pass the TOEFL test especially in reading section. The problem in line as stated by Puspita (2017), there are several things that become obstacles in the reading class faced by students, namely: dependence on teachers, failure to understand reading strategies for different purposes, lackof understanding of what is read, inability to rearrange 
the context of reading, and related vocabulary. That why the researchers want to find out the difficulties of the students in mastering Reading Text in English Department of Muhammadiyah Aceh University.

\section{METHODS}

This study is a qualitative research. Qualitative research can help researchers to access the thoughts and feelings of research participants, which can enable development of an understanding of the meaning that people ascribe to their experiences Sutton, J., \& Austin, Z. (2015). It is a scientific method of observation to gather non-numerical data. This type of research refers to the meanings, concepts definitions, characteristics, metaphors, symbols, and description of things.

A population consist the total of all the individuals who have certain characteristics the researcher wants to measure and a sample consists of the subset of the population selected randomly (Moore, McCabe \& Craig, 2009). Population is also defined as the totality of the research subject, while sample is portion of the population that is researched in a research (Arikunto,2014). In the other words, population is the whole subject which is involved in research.

Sample is a part of object that is wanted to do research. A research is usually executed using a small sample from the population Basuki (2006: 56). The purpose is usually to be able to find genuine facts about the actual small sample that are likewise genuine in the population. In conclusion, the results from the sample can be inferred to the population.

The population of this study includes all students of the first semester in the academic year 2018/2019 from Intensive Reading Comprehension class of English department at Islamic Studies Faculty of Muhammadiyah Aceh University, it consists of 23 students while the sample of this study were 10 of them.

Random sampling technique was used in order to select the sample for this research. Random sampling is a part of the sampling technique in which each sample has an equal probability of being chosen. It is one of the simplest forms of collecting data from the total population. Under random sampling, each member of the subset carries an equal opportunity of being chosen as a part of the sampling process (TheEconomicTimes, n.d.).

In collecting the data, two instruments were applied namely question sheets and interview. The question sheets were distributed by the writer to the students. It helped the writer to get the data about the students' difficulties in mastering reading text, especially about understanding main idea. While interview, the writer received more information their problems.

The research was completed at English department at Islamic Studies Faculty of Muhammadiyah Aceh University, Banda Aceh. The duration of the research was one month with four meetings, started from the second week of July and finished in the middle of August, 2019.

\section{RESULT AND DISCUSSION}

The writer did this study at English Department of Muhammadiyah Aceh University. She distributed the question sheets and interviewed the participants. The question was in open procedure form. It means that the participants could write down their ideas or answers freely as what in their thoughts and interview to cross check their answer.

The questioner consists of 10 questions which were identified 4 questions about main idea, 3 questions about vocabulary, 1 question about inference and 2 questions about reference. Thus, question related to main idea are question number $1,5,8$, and 10 . The name of students were labeled as S1, S2 until S10.

Table 1. Question about Main Idea

\begin{tabular}{cccc}
\hline No & Student (Label) & No. Question & Result \\
\hline 1 & $\mathrm{~S} 1$ & $1,5,8$ & Incorrect \\
2 & $\mathrm{~S} 2$ & $1,5,8$ & Incorrect \\
3 & $\mathrm{~S} 3$ & $1,5,8,10$ & Correct \\
4 & $\mathrm{~S} 4$ & $5,8,10$ & Incorrect \\
5 & $\mathrm{~S} 5$ & 1,5 & Incorrect \\
6 & $\mathrm{~S} 6$ & $1,5,8,10$ & Incorrect \\
7 & $\mathrm{~S} 7$ & $1,5,8,10$ & Incorrect \\
8 & $\mathrm{~S} 8$ & $1,5,8,10$ & Correct \\
9 & $\mathrm{~S} 9$ & $1,5,10$ & Incorrect \\
10 & $\mathrm{~S} 10$ & $1,5,10$ & Incorrect \\
\hline
\end{tabular}

The statistical result indicated that all questions were answered correctly by 2 students (S3 and S8), 2 questions by 1 student (S5), 1 questions by 5 students (S1, S2, S4, S9, and S10) while the rest of 2 students (S6 and S7) answered all of the questions were incorrect.

The data shows that 8 students did not like the subject, while the rest said that they did not know how to say exactly, but they were not really into it. Their sense of thought was not in to this subject, it effects their motivation to study. It means, the students were not motivated enough to improve their reading ability. The students expressed their idea that they dislike the subject because they had wrong basic thought that this subject is a boring one and difficult. Most of them had problems with vocabulary mastery so that they could get the main topic or idea from the text. At the other hand, most of them could answer the questions about reference. Moreover, to solve the difficulties that they faced in understanding main idea or reading comprehension broadly, they tried to dive into reading comprehension lesson by keep practicing in the classroom, having a solid study group, and asking the lecturer to help them by finding and applying the appropriate and interesting methods or techniques.

Other result shown that the students had difficulty about vocabulary. Selecting which words to use related to the context of the sentence sometimes is not as easy as it seems. Students need to understand the whole meaning of a word and memorize 
new words. The students might have memorized it but they rarely or even never use it in their daily conversation or in writing activities, so they need to keep practicing any words to develop their reading ability. Here is the source of that they got confused in mastering main idea because they did not know the word meaning, the usual location of the main idea or they could not paraphrase the main sentence in the text. Since the main idea is different from main sentence, they have to express the idea with other phrase or interpret it. In short, they were poor in understanding sentence.

The main problem is that about vocabulary knowledge. This could be caused by their low motivation of reading activities. Reading can help students to get more new words. They should arrange any support strategies to improve their vocabulary mastery. Besides that, the lecturer should find and apply any interesting ways to create positive atmosphere in the classroom. The lecturer also could ask the students to bring dictionary and write down the difficult words that they found duringreading activities. It could increase students' motivation to read and help them memorize the vocabulary.

\section{CONCLUSION}

Reading is the ability to understand the written text. It helps students to understand the information of what they read. So, reading skills is an important skill that must be mastered by students. The limited knowledge or less vocabulary is considered as the difficulties faced by students in finding and understanding main idea. In order to overcome this situation the students try some ways to improve their reading such as practicing reading as often as possible, learning in group, and asking the lecturer. Likewise, the lecturer should also serve students by interactive learning for reading activities in order to overcome the feeling of flatness in the class.

Moreover, from this study, to improve students in having a good understanding reading and finding main idea suggest that all students must try to read not only in learning but also in a free time and also the lecturer must use the creative and innovative strategy in teaching reading so that students will be motivated and interested.

\section{REFERENCES}

According to Khairunnisa, Students' TOEFL score in Reading Section were low (personal communication, June 22, 2019).

Arikunto, S. (2014). ProsedurPenelitianSuatuPendekatanPraktikPraktik. Jakarta: PT RinekaCipta.

Asher, S. R. (2017). Topic interest and children's reading comprehension. In Theoretical issues in reading comprehension (pp. 525-534). Routledge.

Atikah, I. (2009). Analysis on the Students' Linguistic Problems in Reading Comprehension: A Case Study at Second Grade Students of MTs.BaiturrahmahSukabumi. Retrieved fromhttp://repository.uinjkt.ac.id/dspace/bitstream/123456789/7192/1/IK AH\%20ATIKAH-FITK.pdf

Basuki, (2006). MetodePenelitian. Jakarta: WedatamaWidya Sastra danFakultas IImuPengetahuanBudayaUniversitas Indonesia. independent learners. Guilford Publications.

Cain, K., \& Oakhill, J. (2014). Reading comprehension and vocabulary: Is vocabulary more important for some aspects of comprehension?.LAnneepsychologique, 114(4), 647-662.

Duffy, G. G. (2009). Explaining reading: A resource for teaching concepts, skills, and strategies. Guilford Press.

Duke, N. K., \& Pearson, P. D. (2009). Effective practices for developing reading comprehension. Journal of education, 189(1-2), 107-122.

Goodman, J. On Reading. Acta Anal 35, 51-59 (2020). https://doi.org/10.1007/s12136-019-00400-5.

Hidayati, D. (2018). Students Difficulty in Reading Comprehension at the First Grade of SMAN 1 Darussalam Aceh Besar. Retrieved from https://repository.ar-raniry.ac.id/2865/1/DASRUL\%20HIDAYATI.pdf

Klingner, J. K., Vaughn, S., \& Boardman, A. (2015). Teaching reading comprehension to students with learning difficulties, 2/E. Guilford Publications.

Laily, R,N (2018). The Analysis on Students' Difficulties in Doing Reading Comprehension Final Test Metathesis: Journal of English Language Literature and Teaching, 2 (2), 253-264.

Mandernach, B. J., Zafonte, M., \& Taylor, C. (2016). Instructional Strategies to Improve College Students' APA Style Writing. International Journal of Teaching and Learning in Higher Education, 27(3), 407-412.

Moore, D. S., Craig, B. A., \& McCabe, G. P. (2009). Introduction to the practice of statistics. 6th ed. New York, NY: W. H. Freeman and Co.

Nirwan. (2016). Using KWL (Know-Want to Know-Learned) Strategy in Improving Students' Reading Comprehension (Master's thesis). Syiah Kuala Univesity, Banda Aceh.

Oberholzer. (2005). The Relationship Between Reading Difficulties and Academic Performance Among a Group of Foundation Phase Learners who Have Been Identified as Experienced Difficulty with Reading, and Referred For Reading Remediation. Retrievedfrom http://krepublishers.com/02-Journals/IJES/IJES-10-0-000-15-Web/IJES -10-1-000-15-ABST-PDF/IJES-10-1-008-15-707-Kutame-A-P/IJES-101-008-15-707-Kutame-A-P-Tx[2].pdf

Perfetti, C., \&Stafura, J. (2014). Word knowledge in a theory of reading comprehension. Scientific studies of Reading, 18(1), 22-37.

PourhoseinGilakjani, A., \& Ahmadi, S. M. (2011). The Relationship between L2 ReadingComprehension and Schema Theory: A Matter of Text Familiarity. International Journal of Information and Education Technology, 1(2), 142-149.http://dx.doi.org/10.7763/IJIET.2011.V1.24

Salmani-Nodoushan, M. A., \&Alavi, S. M. (2004). APA style and research report writing. ERIC Clearinghouse.

Sasmita, E. (2012). Identifying Students' Abilities in Understanding English Reading Texts: A Case Study at the Second Year Students of SMKN 1 Gangga in Academic Year 2012/2013. Retrieved from http://fkip-unram.ac.id/ejurnal/index.php/inggris/article/view/235.

Schwartz, B. M. (2016). An Easyguide to APA style. Sage Publications.

Sutton, J., \& Austin, Z. (2015). Qualitative Research: Data Collection, Analysis, and Management. The Canadian journal of hospital pharmacy, 68(3), 226-231. https://doi.org/10.4212/cjhp.v68i3.1456.

The Economic Times.(n.d.). Retrieved fromhttps://economictimes.indiatimes.com/definition/random-sampling

Van den Broek, P., \&Espin, C. A. (2012). Connecting cognitive theory and assessment: Measuring individual differences in reading comprehension. School Psychology Review, 41(3), 315-325.

Blachowicz, C., \& Ogle, D. (2017). Reading comprehension: Strategies for 